\title{
Fatty Alcohols Isolated from Prosopis africana and Evaluation of Antibacterial and Antituberculosis Activities
}

\author{
Nganso Ditchou Yves Oscar ${ }^{1,}$, Soh Desire $^{2}$, Ndogo Eteme Olivier ${ }^{3}$, Mala Opono M. T. G. ${ }^{4}$, \\ Nyasse Barthelemy ${ }^{3}$ \\ ${ }^{1}$ Department of Chemistry, Faculty of Science, University of Maroua, Maroua, Cameroon \\ ${ }^{2}$ Department of Organic Chemistry, Higher Teachers Training College, University of Bamenda, Bamenda, Cameroon \\ ${ }^{3}$ Department of Organic Chemistry, Faculty of Science, University of Yaounde I, Yaounde, Cameroon \\ ${ }^{4}$ Department of Biochemistry, Faculty of Science, University of Yaounde I, Yaounde, Cameroon
}

Email address:

nganso_yves@yahoo.fr (N. D. Y. Oscar)

${ }^{*}$ Corresponding author

\section{To cite this article:}

Nganso Ditchou Yves Oscar, Soh Desire, Ndogo Eteme Olivier, Mala Opono M. T. G., Nyasse Barthelemy. Fatty Alcohols Isolated from Prosopis africana and Evaluation of Antibacterial and Antituberculosis Activities. Journal of Diseases and Medicinal Plants.

Vol. 4, No. 5, 2018, pp. 128-132. doi: 10.11648/j.jdmp.20180405.12

Received: October 6, 2018; Accepted: November 5, 2018; Published: December 3, 2018

\begin{abstract}
Prosopis africana, Family Leguminoceae, is used in ethnomedicine to treat different ailments including, diarrhoea, bacillary dysentery, malaria, male sterility and as a cardiotonic. This research aims at evaluating the antibacterial and antituberculosis activities of fatty alcohol. Heneicosanol (1), hexacosanol (2), nonacosanol (3), $\beta$-sitosterol (4), quercetin (5), $\beta$-sitosterol 3-O- $\beta$-D-glucopyranoside (6) and quercitrin (7) were isolated from the leaves of Prosopis africana. Their structures were elucidated on the basis of a spectroscopic analysis and a comparison of their data spectral with those reported in the literature. Heneicosanol (1), hexacosanol (2), nonacosanol (3) were isolated for the first time to this plant and was subject of antibacterial and antituberculosis activities. The results of this study suggest that the compounds 1, 2, 3 had an MBC a respective value of $1.56 \mu \mathrm{g} / \mathrm{mL}, 1.62 \mu \mathrm{g} / \mathrm{mL}, 0.12 \mu \mathrm{g} / \mathrm{mL}$ against $M$. smegmatis, M. tuberculosis. The study of fatty alcohols provides evidence of activity against clinical isolate of mycobacteria, significant anti-inflammatory and analgesic properties, and provides a basis for its possible use as an affordable and effective Antituberculosis agent from natural product.
\end{abstract}

Keywords: Prosopis africana, Fatty Alcohols, Antibacterial Activities, Antituberculosis Activities

\section{Introduction}

Woody plants have been known to produce many biologically active metabolites. In addition to the studies on chemical constituents of herbal medicinal plants, our phytochemical program also targets woody plants as potential sources of useful natural compounds. Prosopis africana is a woody plant that reaches up to $10-15 \mathrm{~m}$ in height. The bark is used to treat diarrhoea, bacillary dysentery, and inflammatory diseases $[1,2]$. The study on Prosopis africana should be of interest since the constituents of Prosopis species have been demonstrated to possess antioxidant [3, 4], anti-inflammatory [5-8], anticancer [9, 10] and hepatoprotective effects [3, 11]. In this paper the isolation and structural elucidation of seven compounds, heneicosanol (1), hexacosanol (2), nonacosanol (3), $\beta$ sitosterol (4), quercetin (5), $\beta$-sitosterol 3-O- $\beta$ - $\mathrm{D}$ glucopyranoside (6), and quercitrin (7) (Figure 1) from the $\mathrm{MeOH}$ extract of the leaves of Prosopis aficana. Heneicosanol (1), hexacosanol (2), nonacosanol (3) were isolated from this plant for the first time. The goal of this study is evaluating the antibacterial and antituberculosis activities of the fatty alcohol isolated for the first time from the leaves of Prosopis africana.

\section{Experimental}

\subsection{General Procedure}

Electron-impact (EI) mass spectra $(70 \mathrm{eV})$ were measured 
on a Hewlett-Packard 5989B mass spectrometer. Electrospray Ionization (ESI) mass spectra were recorded on a LC/MSD Trap Agilent Series 1100 system with an ESI source. ${ }^{1} \mathrm{H}$ NMR $(500 \mathrm{MHz})$ and ${ }^{13} \mathrm{C}$ NMR $(125 \mathrm{MHz})$ with DEPT program spectra were obtained on a Bruker Avance 500 NMR spectrometer. Tetramethyl silane (TMS) was used as zero reference. Silica gel $60 \quad(63-200 \mu \mathrm{m}$, Merck, Darmstadt, Germany) was used for open column (CC) and silica gel 60 (15-40 and 40-63 $\mu \mathrm{m}$, Merck, Darmstadt, Germany) for flash column (FC) chromatography. TLC was performed on precoated DC Alufolien $60 \mathrm{~F}_{254}$ sheets (Merck, Darmstadt, Germany) and detected by UV light ( $\lambda 254 \mathrm{~nm}$ ) or by spraying with $1 \%$ vanillin in conc $\mathrm{H}_{2} \mathrm{SO}_{4}$.

\subsection{Plant Material}

The fresh leaves of Prosopis africana were identified and collected by Dr. Froumsia Moskia Department of Biology Science, Faculty of Science, University of Maroua, Cameroon.

\subsection{Extraction and Isolation}

The air-dried leaves of Prosopis africana (232 g) were oven-dried at $40^{\circ} \mathrm{C}$, then powdered and extracted with $\mathrm{MeOH}$ by percolation ( 6 times) at room temperature. The combined $\mathrm{MeOH}$ extract was concentrated under reduced pressure. The resultant $\mathrm{MeOH}$ extract was suspended in $\mathrm{H}_{2} \mathrm{O}$ and partitioned successively with $n$-hexane, $\mathrm{CH}_{2} \mathrm{Cl}_{2}$ and EtOAc. Part of the $n$-hexane-soluble fraction (26g) was chromatographed on silica gel CC using a gradient $n$-hexaneEtOAc solvent system ( $n$-hexane; $n$-hexane-EtOAc 7:1, 4:1, $2: 1$, and 1:1; and EtOAc). Four pooled fractions were collected on the basis of the volumes of eluents and TLC analysis; fraction A $(0.78 \mathrm{~g})$ was eluted with $n$-hexane; fractions B (0.54 g), C (0.66 g), and D (0.84 g) with $n$ hexane-EtOAc 7:1;

Separation of fraction A on silica gel CC ( $n$-hexane-EtOAc $90: 1)$ gave $1(21.3 \mathrm{mg}), 2(22 \mathrm{mg})$ after recrystallization from $n$-hexane-EtOAc 9:1, and 3 (30 mg).

Fraction B was chromatographed by silica gel CC (gradient $n$-hexane-EtOAc 30:1, 15:1, 7:1 and 4:1) and one of the fractions obtained was recrystallized from $\mathrm{CH}_{2} \mathrm{Cl}_{2}$ to give 4 (8 mg), 5 (8.8mg), 6 (7.6mg) and 7 (11.4mg).

Heneicosanol (1): $21.3 \mathrm{mg}$. Crystalline white solid. M.p. $68^{\circ} \mathrm{C}$ (hexane/AcOEt). FT-IR: 3442, 2919, 2850, 1735, 1466, $724 \mathrm{~cm}^{-1}$. The ${ }^{1} \mathrm{H}$ NMR spectrum displayed the typical signals $0.88\left(3 \mathrm{H}, \mathrm{t}, \mathrm{J}=7 \mathrm{~Hz}, \mathrm{CH}_{3}\right), 1.25\left(2 \mathrm{H}, \mathrm{m},\left(\mathrm{CH}_{2}\right) \mathrm{n}\right), 1.57$ $\left(2 \mathrm{H}, \mathrm{t}, \mathrm{J}=6.5 \mathrm{~Hz}, \mathrm{CH}_{2}\right), 3.65\left(2 \mathrm{H}, \mathrm{t}, \mathrm{J}=6.5 \mathrm{~Hz}, \mathrm{CH}_{2}-\mathrm{OH}\right)$. In the ${ }^{13} \mathrm{C}$ NMR spectrum showed different C-atom $14.1\left(\mathrm{CH}_{3}\right)$, $22.7\left(\mathrm{CH}_{2}\right), 25.7\left(\mathrm{CH}_{2}\right), 29.4\left(\mathrm{CH}_{2}\right), 29.6\left(\mathrm{CH}_{2}\right), 31.9\left(\mathrm{CH}_{2}\right)$, $32.8\left(\mathrm{CH}_{2}\right), 63.1\left(\mathrm{CH}_{2}\right)$. EI-MS $(70 \mathrm{eV}): 312\left(3, \mathrm{M}^{+}\right), 227(5)$, 125(9), 111(18), 97(35), 83(48), 69 (52), 57(77), 43 (100).

Hexacosanol(2): ESIMS showed $[\mathrm{M}+1]^{+}$at $\mathrm{m} / \mathrm{z} 383.2057$ indicating a molecular formula of $\mathrm{C}_{26} \mathrm{H}_{54} \mathrm{O} .{ }^{13} \mathrm{C}$ NMR $\left(\mathrm{CDCl}_{3}, 100 \mathrm{MHz}\right): \mathrm{d}_{\mathrm{C}} 63.1\left(\mathrm{CH}_{2}-\mathrm{OH}\right), 32.7\left(\mathrm{CH}_{2}\right), 31.9$

$\left(\mathrm{CH}_{2}\right), 29.4\left(\mathrm{CH}_{2}\right), 29.3\left(\mathrm{CH}_{2}\right), 29.2\left(\mathrm{CH}_{2}\right), 25.4\left(\mathrm{CH}_{2}\right)$, $22.7\left(\mathrm{CH}_{2}\right), 14.2\left(\mathrm{CH}_{3}\right)$ indicating unsaturated primary fatty alcohol.

Nonacosanol(3): White amorphous powder. Rf 0.5 (nhexane-EtOAc 4:1). EI-MS: m/z $364\left(\mathrm{M}+., \mathrm{C}_{29} \mathrm{H}_{60} \mathrm{O},-60\right)$. ${ }^{1} \mathrm{H}$ NMR $\left(\mathrm{CDCl}_{3}\right): \delta 0.88(3 \mathrm{H}, \mathrm{t}, \mathrm{J}=7.0 \mathrm{~Hz}, \mathrm{H}-29), 1.2650 \mathrm{H}$, br s), $1.58(4 \mathrm{H}, \mathrm{m}(2 \mathrm{H}-2 \rightarrow 2 \mathrm{H}-28), 3.64(2 \mathrm{H}, \mathrm{t}, \mathrm{J}=6.5 \mathrm{~Hz}$, $\mathrm{H}-1)$.

$\beta$-Sitosterol (4): White amorphous powder. $\mathrm{R}_{\mathrm{f}} 0.37$ ( $\mathrm{n}$ hexane-EtOAc 4:1). The Co-TLC analysis is superimposable with that of our authentic sample.

Quercetin (5): Yellow needles. $\mathrm{R}_{\mathrm{f}} 0.54\left(\mathrm{CH}_{2} \mathrm{Cl}_{2}-\left(\mathrm{CH}_{3}\right)_{2} \mathrm{CO}\right.$ 2:1). ESI-MS: $\mathrm{m} / \mathrm{z} 302.9[\mathrm{M}+\mathrm{H}]^{+}$(positive mode), $\mathrm{m} / \mathrm{z} 301.0$ $[\mathrm{M}-\mathrm{H}]^{-}$(negative mode). ${ }^{1} \mathrm{H} \mathrm{NMR}\left(\mathrm{CD}_{3} \mathrm{OD}\right): \delta 6.2(1 \mathrm{H}, \mathrm{d}, J$ $=2.0 \mathrm{~Hz}, \mathrm{H}-8), 6.4(1 \mathrm{H}, \mathrm{d}, J=2.0 \mathrm{~Hz}, \mathrm{H}-6)$,

$6.90\left(1 \mathrm{H}, \mathrm{d}, J=8.5 \mathrm{~Hz}, \mathrm{H}-5^{\prime}\right), 7.64(1 \mathrm{H}, \mathrm{dd}, J=8.5 \mathrm{~Hz}$, $\left.2.5 \mathrm{~Hz}, \mathrm{H}-6^{\prime}\right), 7.75\left(1 \mathrm{H}, \mathrm{d}, J=2.5 \mathrm{~Hz}, \mathrm{H}-2^{\prime}\right) .{ }^{13} \mathrm{C}-\mathrm{NMR}$ $\left(\mathrm{CD}_{3} \mathrm{OD}\right): \delta 94.4$ (d, C-8), 99.2 (d, C-6), 104.5 (s, C-10), $116.0\left(\mathrm{~d}, \mathrm{C}-2^{\prime}\right), 116.2$

(d, C-5'), 121.7 (s, C-6'), 124.1 (s, C-1'), 137.2 (s, C-3), 146.2 (s, C-3'), 148.0 (s, C-2), 148.7 (s, C-4'), 158.2 (s, C-9), 162.5 (s, C-5), 165.5 (s, C7), 177.3 (s, C-4).

$\beta$-Sitosterol-3-O- $\beta$-D-glucopyranoside (6): White amorphous powder. $\mathrm{R}_{\mathrm{f}} 0.54\left(\mathrm{CH}_{2} \mathrm{Cl}_{2}\left(\mathrm{CH}_{3}\right)_{2} \mathrm{CO} 1: 3\right)$. The ${ }^{1} \mathrm{H}$ NMR $\left(\mathrm{CD}_{3} \mathrm{OD}\right)$ is identical with that of our authentic sample.

Quercitrin (7): Yellow needles. $\mathrm{R}_{\mathrm{f}} 0.57\left(\mathrm{CH}_{2} \mathrm{Cl}_{2}-\left(\mathrm{CH}_{3}\right)_{2} \mathrm{CO}\right.$ 1:3). EI-MS: m/z $302\left(\mathrm{M}^{+}, \mathrm{C}_{21} \mathrm{H}_{20} \mathrm{O}_{11},-146\right)$. ${ }^{1} \mathrm{H}-\mathrm{NMR}$ $\left(\mathrm{CD}_{3} \mathrm{OD}\right): \delta 0.96\left(3 \mathrm{H}, \mathrm{d}, J=6.0 \mathrm{~Hz}, 5^{\prime \prime}-\mathrm{CH}_{3}\right), 3.33(1 \mathrm{H}, \mathrm{m}$, H-4"), 3.44 (1H, m, H-3"), 3.77 (1H, dd, $J=8.0 \mathrm{~Hz}, 3.5 \mathrm{~Hz}$, $\left.\mathrm{H}-2^{\prime \prime}\right), 4.24$ (1H, m, H-5"), 5.37 (1H, d, $\left.J=1.0 \mathrm{~Hz}, \mathrm{H}-1^{\prime \prime}\right)$, $6.22(1 \mathrm{H}, \mathrm{d}, J=2.0 \mathrm{~Hz}, \mathrm{H}-8), 6.39(1 \mathrm{H}, \mathrm{d}, J=2.0 \mathrm{~Hz}, \mathrm{H}-6)$, $6.93\left(1 \mathrm{H}, \mathrm{d}, J=8.5 \mathrm{~Hz}, \mathrm{H}-5^{\prime}\right), 7.32(1 \mathrm{H}, \mathrm{dd}, J=8.5 \mathrm{~Hz}, 2.0$ $\left.\mathrm{Hz}, \mathrm{H}-66^{\prime}\right), 7.36\left(1 \mathrm{H}, \mathrm{d}, J=2.0 \mathrm{~Hz}, \mathrm{H}-2^{\prime}\right) .{ }^{13} \mathrm{C}$ NMR

$\left(\mathrm{CD}_{3} \mathrm{OD}\right): \delta 17.6\left(\mathrm{q}, \mathrm{C}-6^{\prime \prime}\right), 71.9\left(\mathrm{~d}, \mathrm{C}-5^{\prime \prime}\right), 72.0$ (d, C-3"), 72.1 (d, C-2"), 73.3 (d, C-4"), 94.7 (d,

C-8), 99.8 (d, C-6), 103.6 (d, C-1"), 105.9 (s, C10), 116.4 (d, C-2'), 117.0 (d, C-5'), 122.9 (s, C6'), 123.0 (s, C-1'), 136.3 (s, C-3), 146.4 (s, C-3'), 149.8 (s, C-4'), 158.5 (s, C-2), 159.3 (s, C-9), 163.2 (s, C-5), 165.8 (s, C-7), 179.6 (s, C-4).

\subsection{Antibacterial Activity}

\subsubsection{In Vitro Evaluation of the Antibacterial Activity of the Crude Extracts}

$7.6 \mathrm{~g}$ of Mueller Hinton Agar (MHA) was dissolved in 200 $\mathrm{mL}$ of distilled water and then heated on autoclave at $121{ }^{\circ} \mathrm{C}$ for $30 \mathrm{~min}$. After cooling the mixture was poured into the petri dishes near the beak of Bunsen burner [12].

\subsubsection{Liquid Medium}

$13.65 \mathrm{~g}$ of Mueller Hinton Broth (MHB) were dissolved in $650 \mathrm{~mL}$ of distilled water. A part of this medium was distributed in tubes of $15 \mathrm{~mL}(10.853 \mathrm{~mL}$ per tube which will be used for inocula). Another part was distributed in the 2 $\mathrm{mL}$ tubes $(1.7 \mathrm{~mL}$ per tube for the dilution of the extracts). These tubes and the rest of medium were heated in an autoclave at $121^{\circ} \mathrm{C}$ for $30 \mathrm{~min}$ [13].

\subsubsection{Culture of Bacterial Strains}

The different bacterial strains were subcultured by the 
method of the streaks on MHA agar medium poured into the Petri dishes. The petri dishes were introduced into the incubator at $37^{\circ} \mathrm{C}$. For 18 hours in order to obtain a young culture and isolated colonies. The isolated colonies were used to prepare the inoculum $[13,14]$.

\subsection{Antituberculosis Activity}

\subsubsection{Preparation of the Inoculums}

Using a sterile platinum loop, a few colonies of bacteria from each strain were taken from the activation medium and each introduced into a tube containing a sterile physiological solution $(0.9 \% \mathrm{NaCl})$. The contents of each tube were homogenized using the vortex in order to obtain a turbidity comparable to the standard scale of Mc Farland (Table 1) corresponding to the concentration of 1.5 . $108 \mathrm{CFU} / \mathrm{mL}$. Subsequently, $147 \mu \mathrm{L}$ of the resulting suspension was removed and introduced into $10.85 \mathrm{~mL}$ of MHB for a volume of $11000 \mathrm{~mL}$ of an inoculated medium at $2.10^{6} \mathrm{CFU} / \mathrm{mL}$ [15].

\subsubsection{Antitubercular Rapid Radiometric Assay Using M. Tuberculosis}

A sensitive strain of $M$. tuberculosis, the H37Rv references strain, was used in the screening procedure. A standard inoculum was prepared for the sensitive strain in Middlebrook Dubos $7 \mathrm{H} 9$ broth containing 0,5\% Tween 80 to obtain a concentration of $1.0 \mathrm{mg} / \mathrm{mL}$ (wet mass). The bacterial cultures, which were used to prepare the standard inoculum, were maintained on Lowenstein-Jensen medium. A representative amount of growth was taken from the cultures by using a sterile applicator stick. This sample was transferred to a sterile $16 \times 125 \mathrm{~mm}$ screw capped round tube containing six to eight glass beads $(1-2 \mathrm{~mm})$ and $3.0-4.0$ $\mathrm{mL}$ of the diluting fluid $(0,1 \%$ Tween $)$. A homogenous suspension was obtained by placing the tube on the Vortex mixer for five minutes and then left for 15 minutes to allow the particles to settle. After the large particles had settled, the supernatant, a homogeneous suspension was transferred into a separate sterile test tube and more Tween was added and adjusted approximately to McFarland no 1 turbidity standards [16].

\subsubsection{Antituberculosis Activity Against M. Smegmatis and M. Tuberculosis}

Solutions of all the extracts were prepared in DMSO to obtain a stock concentration of $500.0 \mathrm{mg} / \mathrm{mL}$. Control experiments showed that a final concentration of DMSO $(1 \%)$ in the medium had no adverse effect on the growth of M. tuberculosis. Isoniazid (INH; Sigma-Aldrich) at a final concentration of $0.2 \mu \mathrm{g} / \mathrm{mL}$ served as the drug-control in our bioassay. All the extracts were tested at concentrations ranging from 5.0 to $0.1 \mathrm{mg} / \mathrm{mL}$. A homogenous culture $(0.1$ $\mathrm{mL}$ of $M$. tuberculosis, yielding $1 \times 10^{4}$ to $\left.1 \times 10^{5} \mathrm{CFU} / \mathrm{mL}\right)$, was inoculated into the vials containing the extracts, as well as in the control vials. Three extract-free vials were used as controls (medium $+1 \%$ DMSO), two vials (V1) were inoculated in the same way as the vials containing the extracts, and one (V2) was inoculated with a 1:100 dilution of the inoculum $(1: 100$ control $)$ to produce an initial concentration representing $1 \%$ of the bacterial population (1 $\mathrm{x} 10^{2}$ to $1 \times 10^{3} \mathrm{CFU} / \mathrm{mL}$ ). The MIC was defined as the lowest concentration of the extract that inhibited $>99 \%$ of the bacterial population. When Mycobacterium grows in $7 \mathrm{H} 12$ medium containing a 14C-labelled substrate (palmitic acid), they use the substrate and $14 \mathrm{CO}_{2}$ is produced. The amount of $14 \mathrm{CO}_{2}$ detected reflects the rate and amount of growth occurring in the sealed vial and is expressed in terms of the growth index [16]. Inoculated bottles were incubated at $370^{\circ} \mathrm{C}$ and each bottle was assayed at 24 hours intervals at about the same time until cumulative results were interpretable to measure the GI. The difference in the GI values of the last two days was designated as $\Delta \mathrm{GI}$. The GI readings of the vials containing the test extracts were compared with the control vials (V2). Readings were taken until the control vials, containing a 100 times lower dilution of the inoculum than the test vials, reached a GI of 30 or more. If the $\Delta \mathrm{GI}$ values of the vials containing the test extracts were less than the control vials, the population was reported to be susceptible to the compound and if it was equal to or greater than that in the control vials, the test organisms were considered to be resistant to the drugs. Each test was replicated three times [16-17].

\section{Results and Discussion}

The dried leaves of Prosopis africana were extracted with $\mathrm{MeOH}$, and the resultant $\mathrm{MeOH}$ extract was partitioned between $\mathrm{H}_{2} \mathrm{O}$ and solvents of increasing polarity to give $n$ hexane and EtOAc-soluble fractions. Fractionation of the $n$ hexane and EtOAc-soluble fractions by silica gel open column (CC) and flash column (FC) chromatography resulted in the isolation of seven compounds 1-7 (Figure 1).

Compound 1 was a saturated fatty alcohol (hexacosanol). The 1D and 2D-NMR spectra allowed inferring the presence of one Me and twenty $\mathrm{CH}_{2}$ groups. The ${ }^{1} \mathrm{H}$ NMR spectra displayed the typical signals assigned to $\delta(\mathrm{H}) 0.88(\mathrm{t}, \mathrm{J}=7$, $\left.\mathrm{Me}-\left(\mathrm{C}_{21}\right)\right)$ and $\delta(\mathrm{H}) 3.65\left(\mathrm{t}, \mathrm{J}=6.5, \mathrm{H}\left(\mathrm{C}_{1}\right)\right)$. The presence of the $\mathrm{OH}$ group was deduced from the FT-IR absorption at $3492 \mathrm{~cm}^{-1}$ and by the signal at $63.13 \mathrm{ppm}$ in the ${ }^{13} \mathrm{C}$ NMR spectrum. The location of the $\mathrm{OH}$ group at $\mathrm{C}(1)$ was established by correlation cross-peaks between $\mathrm{H}-\mathrm{C}(1)$ and $\mathrm{H}-\mathrm{C}(2)$ in the ${ }^{1} \mathrm{H}-{ }^{1} \mathrm{H}-\mathrm{COSY}$ spectrum.

Compound 2, heneicosanol was isolated by column chromatography (CC). Spectroscopic techniques such as 1D and 2D-NMR as well as EI-MS were used for structure elucidation. The EI-MS analysis showed an ion peak at $\mathrm{m} / \mathrm{z}$ $312(\mathrm{M}+)$, concordant with the molecular formulae $\mathrm{C}_{21} \mathrm{H}_{44} \mathrm{O}$ (Figure 1). The 1D and 2D-NMR spectra allowed inferring the presence of one $\mathrm{Me}$ and twenty $\mathrm{CH}_{2}$ groups. The ${ }^{1} \mathrm{H}$ NMR spectra displayed the typical signals assigned to $\delta(\mathrm{H})$ $0.88\left(\mathrm{t}, \mathrm{J}=7, \mathrm{Me}-\left(\mathrm{C}_{21}\right)\right)$ and $\delta(\mathrm{H}) 3.65\left(\mathrm{t}, \mathrm{J}=6.5, \mathrm{H}\left(\mathrm{C}_{1}\right)\right)$. In the $\mathrm{HMBC}$ spectrum, correlations were observed between the $\mathrm{H}$-atom resonance of $\mathrm{Me}(21)(\delta(\mathrm{H}) 0.88)$ and that of $\mathrm{C}(20)$; the resonance of $\mathrm{H}-\mathrm{C}(1)(\delta(\mathrm{H}) 3.65)$ and that of $\mathrm{C}(2)$, and the 
resonance of $\mathrm{H}-\mathrm{C}(2)(\delta(\mathrm{H})$ 1.57) and that of $\mathrm{C}(4)$. The presence of the $\mathrm{OH}$ group was deduced from the FT-IR absorption at $3492 \mathrm{~cm}^{-1}$ and by the signal at $63.13 \mathrm{ppm}$ in the ${ }^{13} \mathrm{C}$ NMR spectrum. The location of the $\mathrm{OH}$ group at $\mathrm{C}(1)$ was established by correlation cross-peaks between $\mathrm{H}-\mathrm{C}(1)$ and $\mathrm{H}-\mathrm{C}(2)$ in the ${ }^{1} \mathrm{H}-{ }^{1} \mathrm{H}-\mathrm{COSY}$ spectrum.
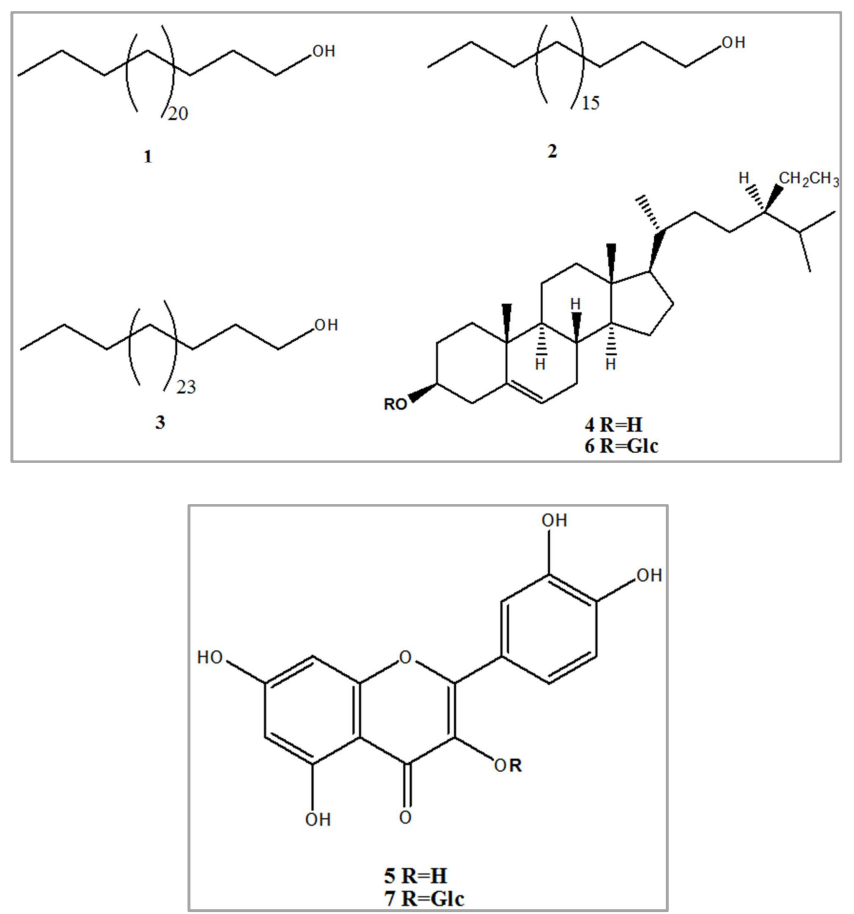

Figure 1. Structure of compounds 1 to 7 isolated from Prosopis africana.
Compound 3 was isolated as a white amorphous powder $\left[\mathrm{R}_{\mathrm{f}} 0.5\right.$ (n-hexane-EtOAc 4:1)] from the $n$-hexane-soluble fraction. 3 was determined to be nonacosanol from its ${ }^{1} \mathrm{H}$ NMR spectroscopic data. In the ${ }^{1} \mathrm{H}$ NMR spectrum of 3 the terminal methyl group $\left.\delta_{\mathrm{H}} 0.88(3 \mathrm{H}, \mathrm{t}, J=7.0 \mathrm{~Hz})\right]$, methylene chains $\left[\delta_{\mathrm{H}} 1.26(50 \mathrm{H}\right.$, br s) and $1.58(4 \mathrm{H}, \mathrm{m})]$, and a methylene group bearing a hydroxy group $\left[\delta_{\mathrm{H}} 3.64(2 \mathrm{H}, \mathrm{t}, J=\right.$ $6.5 \mathrm{~Hz})]$ were observed. The number of methylene groups was deduced to be 28 from the ${ }^{1} \mathrm{H}$ NMR integration. The EIMS spectrum of 3 showed the highest peak at $m / z 364$, which was probably derived from simultaneous loss of $\mathrm{H}_{2} \mathrm{O}$ and ethylene, and a methylene group $\left(\mathrm{M}^{+}, \mathrm{C}_{29} \mathrm{H}_{60} \mathrm{O},-18-28-\right.$ 14). Nonacosanol was found as constituent of several species, Agave, Sisalana, Citrulus, and Rhizophora [18, 19].

\subsection{Antimicrobial and Antituberculosis Activities}

The antimicrobial tests carried out on compounds 1 to 3 led to the following results: Compounds 1 to 3 exhibited antimicrobial activity against Candida albicans and Candida krusei, with MIC values of $250 \mu \mathrm{g} / \mathrm{mL}$ for both yeast species. They were also tested against two Gram-negative bacteria (Escherichia coli, Pseudomonas aeruginosa) and Gram-positive bacteria (Staphylococcus aureus) and the results obtained from $\mathrm{IC}_{50}$ are respectively: $65.0 \pm 4.1,59.0 \pm$ $6.8,57.0 \pm 1.7(\mu \mathrm{g} / \mathrm{mL})$, for a concentration of $3.20 \mu \mathrm{g} /$ $\mathrm{mL} ; 4.8 \mu \mathrm{g} / \mathrm{mL} 5.2 \mu \mathrm{g} / \mathrm{mL}$. This suggests that these compounds are active on these elements. The antituberculosis tests were also performed and the results are recorded in Table 1 below.

Table 1. Antimycobacterial activity of the compounds 1, 2 and 3 against M. smegmatis and M. tuberculosis.

\begin{tabular}{|c|c|c|c|c|}
\hline \multirow[t]{2}{*}{ Tested samples } & \multicolumn{2}{|l|}{ M. smegmatis } & \multicolumn{2}{|l|}{ M. tuberculosis } \\
\hline & $\mathrm{MIC}(\mu \mathrm{g} / \mathrm{mL})$ & $\mathrm{MBC}(\mathrm{mg} / \mathrm{mL})$ & $\mathrm{MIC}(\mathrm{mg} / \mathrm{mL})$ & $\Delta \mathbf{G I}$ \\
\hline Compound 1 & 0.78 & 1.56 & $1.20(\mathrm{~S})$ & $0.0 \pm 0.0$ \\
\hline Compound 2 & 0.80 & 1.62 & $1.3(\mathrm{~S})$ & $0.0 \pm 0.0$ \\
\hline Compound 3 & 0.03 & 0.12 & $0.10(\mathrm{~S})$ & $8.0 \pm 2.8$ \\
\hline Ciprofloxacin (positive drug control for $M$. smegmatis) & 0.15 & 0.31 & nd & nd \\
\hline Isoniazid (positive drug control for M.tuberculosis) & nd & nd & $2 \times 10^{-4}(\mathrm{~S})$ & $13.0 \pm 0.7$ \\
\hline
\end{tabular}

MIC: Minimum inhibitory concentration.

MBC: Minimum bactericidal concentration.

$\Delta \mathrm{GI}$ : value (mean $\pm \mathrm{SD}$ ) of the control vial $(10), 38.0 \pm 3.8$ for the sensitive strain.

S: Susceptible.

nd: Not determined.

In the present study, compounds 1, 2 and 3 were subject to antituberculosis activities. Compound 1 was found to be active at $0.78 \mu \mathrm{g} / \mathrm{mL}$ and $1.20 \mu \mathrm{g} / \mathrm{mL}$ against $M$. smegmatisand $M$. tuberculosis respectively. Compound 1 had an $\mathrm{MBC}$ of $1.56 \mu \mathrm{g} / \mathrm{mL}$ against $M$. smegmatis (Table 1). Compound 2 was found to be active at $0.80 \mu \mathrm{g} / \mathrm{mL}$ and 1.30 $\mu \mathrm{g} / \mathrm{mL}$ against $M$. smegmatis and $M$. tuberculosis respectively. Compound 2 had an $\mathrm{MBC}$ of $1.62 \mu \mathrm{g} / \mathrm{mL}$ against $M$. smegmatis. Compound 3 was found to be active at $0.03 \mu \mathrm{g} / \mathrm{mL}$ and $0.10 \mu \mathrm{g} / \mathrm{mL}$ against $M$. smegmatis and $M$. tuberculosis respectively. Compound 3 had an $\mathrm{MBC}$ of 0.12 $\mu \mathrm{g} / \mathrm{mL}$ against $M$. smegmatis; The reactivity of these fatty alcohols could be due to the presence of the hydroxyl functional group in their chemical structure, or linked to the length of their molecular chain.

\section{Conclusion}

The results provide a rationale for the use of Prosopis africana in traditional medicine to treat various diseases. This study could be considered as a prelude to the discovery of new antimicrobial agents for bacteria and antituberculosis activities. In addition, the broad-spectrum activity of compounds 1,2 , and 3 revealed that compound 1 is active at $0.78 \mu \mathrm{g} / \mathrm{mL}$ and $1.20 \mu \mathrm{g} / \mathrm{mL}$ against $M$. smegmatis and $M$. tuberculosis, respectively. Compound 2 is active at 0.80 $\mu \mathrm{g} / \mathrm{mL}$ and $1.30 \mu \mathrm{g} / \mathrm{mL}$ against $M$. smegmatis and $M$. tuberculosis respectively. Compound 3 is active at 
$0.03 \mu \mathrm{g} / \mathrm{mL}$ and $0.10 \mu \mathrm{g} / \mathrm{mL}$ against $M$. smegmatis and $M$. tuberculosis respectively. These results provide the opportunity to discover new and effective components for downstream clinical development. Many studies must be conducted to better understand its mode of action and antituberculosis activity.

\section{Acknowledgements}

Dr. Nganso Ditchou Yves Oscar of the Department of Chemistry of the Faculty of Sciences of the University of Maroua, thanks Mr. Ndogo Eteme Olivier of the University of Yaounde I of the Department of Organic Chemistry for his contribution to this work. Mrs Mala Opono MT G of the laboratory of Biochemistry of the University of Yaounde I for the antimicrobial tests and Dr. Froumsia Moskia of the Department of Biological Sciences of the Faculty of Sciences of the University of Maroua for the harvest of Prosopis africana.

\section{References}

[1] Kim ST, Kim JD, Ahn SH, Ahn GS, Lee YI, Yeong YS (2004). Phytother. Res, 18: 971 - 975.

[2] LAOUALI A, GUIMBO ID, LARWANOU M, INOUSSA MM, MAHAMANE A (2014). Utilisation de Prosopis africana (G. et Perr.) Taub dans le sud du département d'Aguié au Niger: les différentes formes et leur importance. International Journal of Biological and Chemical Sciences, 8(3):1065-1074.

[3] Lee MW, Kim JH, Jeong DW, Ahn KH, Toh SH, Surh YJ (2000). Biol. Pharm. Bull, 23: $517-518$.

[4] Madani M, Sirigne OS, Issoufou AM, Dackouo B (2016). Antioxidant activity and phytochemical study of leaf extract of Prosopis africana (Guill \& Perr Taub) an anti-tumor plant used traditionally. Journal of Chemical and Pharmaceutical Research, 8(6):521-525.

[5] Kim HJ, Yeom SH, Kim MK, Shim JG, Paek IN, Lee MW (2005). Arch. Pharm. Res, 28: $177-179$.

[6] Lee CJ, Lee SS, Chen SC, Ho FM, W. Lin WB (2005). $J$. Pharmacol, 146: 378 - 388 .

[7] Kim JH, Lee KW, Lee MW, Lee HJ, Kim SH, Surh YJ (2006). FEBS Lett, 580: 385 - 392.

[8] Lydia OA, Abdullahi HY, Olajumoke MA (2010). Analgesic and anti-inflammatory effects of the methanol stem bark extract of Prosopis Africana. Pharmaceutical Biology, 48(3): 296-299.
[9] Buniatian ND, Chikitkina VV, Iakovleva LV. Eksp (1998). Klin. Farmakol, 61: 53 - 55.

[10] Santhaseelan H, Prabha S, Rathinam AJ, Yi-Hong T, Rahul N, Yang-Chang W, Hans-Uwe D, Fang R C (2017). Biopharmaceutical potentials of Prosopis spp.(Mimosaceae, Leguminosa). journal of food and drug analysis, 25: 187-196.

[11] Osha JAB, Suzu IUA (2015). Comparative studies of the pharmacological activities of Prosopis Africana fruits and its fraction. Medicinal and Aromatic Plant Research Journal, 3(1): 1-8.

[12] Ruhnke M, Schmidt WA, Engelmann E, Trautmann M (1996). Comparative evaluation of three antifungal susceptibility test methods for Candida albicans isolates and correlation with response to fluconazole therapy. Journal of Clinical Microbiology, 34(12): 3208-3211.

[13] Wright L, Scott E, Gorman S (1983). The sensitivity of mycelium, arthrospores and microconidia of Trichophyton mentagrophytes to imidazoles determined by in-vitro tests. Journal of Antimicrobial. Chemotheraphy, 12: 317-327.

[14] Arancibia L, Naspi C, Pucci, G, Arce M (2010). Aromatic plants from Patagonia: Chemical composition and antimicrobial activity of the essential oil of Senecio mustersii and S. subpanduratus. Boletín Latino americano y del Caribe de Plantas Medicinale sy Aromáticas, 9(2):123-126.

[15] Hattori M, Miyachi K, Hada S, Kakiuchi N, Kiuchi F, TSuda Y, Namba T (1987). Effects of long-chain fatty acids and fatty alcohols on the growth of Streptococcus mutans. Chemical and Pharmaceutical Bulletin, 35(8): 3507-3510.

[16] Faizi S, Siddiqi H, Bano S, Naz A, Mazhar K, Nasim S, Riaz T, S, Kamal S, Ahmad A, Khan A (2008). Antibacterial and antifungal activities of different parts of Tagete spatula: preparation of patuletin derivatives. Pharmaceutical Biology, 46(5): 309-320.

[17] Sannah P, NKAMI M (2009). Antituberculosis activity of flavonoids from Galenia africana L. var. africana BY A Submitted in partial fulfilment of the requirements for the degree DOCTOR OF PHILOSOPHIAE: PLANT SCIENCE in the Faculty of Natural \& Agricultural Science University of Pretoria Pretoria. 55-60.

[18] Reina M, González-Coloma A, Cabrera R, Gutierrez C, Rodriguez M, Fajardo V, Villarroel L (2001). Defensive Chemistry of Senecio miser. Journal Natural Products, 64: 611 .

[19] Gonçalves JDS, Vieira IJC, Raimundo BF, Branco A (2015). Chemicals from Agave sisalana Biomass: Isolation and Identification. International Journal of Molecular Sciences, 16:8761-8771. 